\title{
TRANSFORMATION OF CHARITIES BY ISLAMIC SOCIAL MOVEMENTS IN YOGYAKARTA, 1912-1931: A HISTORY OF ISLAMIC WEALTH MANAGEMENT
}

\author{
Ghifari Yuristiadhi ${ }^{1}$, Bambang Purwanto ${ }^{2}$
}

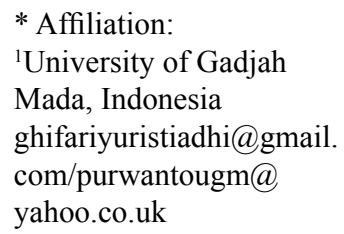

* Affiliation:

${ }^{1}$ University of Gadjah

Mada, Indonesia ghifariyuristiadhi@gmail. com/purwantougm@ yahoo.co.uk

\begin{abstract}
This article was written in order to find a model of the development of Islamic charities organized by bumiputera in the early 20th century in Yogyakarta. This socio-economic history research using historical research methods that utilize primary sources such as archives, photographs, books and newspapers as well as the contemporary of secondary sources such as books, journals, and articles. The conclusion of this article is that the presence of transformation of charities in Yogyakarta in the period 1920s-1930s caused by 1) the dynamic moments around the period of the emergence of privately plantation by European, 2) the implementation of the land reorganization in the region of Yogyakarta Sultanate, 3) the emergence of "urban santri" as the new middle class in urban Yogyakarta, and 4) dynamic Islamic social organizations. In addition, the transformation of charities happens consists of three processes. First, change the concept and definition of waqf be more specific. Secondly, changing of the charities model that presented by the Islamic social movements. Third, shift of waqf and charities authority management that also change management culture. One thing that can be seen from this phenomenon is the emergence of local responses on colonialism with a more elegant and become the new social movements as well as showing the existence of civil society.

Keywords: transformation, Islamic charities, bumiputera, Yogyakarta, Muhammadiyah
\end{abstract}

\section{INTRODUCTION}

In the early twentieth century, the life of the Muslim Bumiputera (Kuntowijoyo, 1991) ${ }^{1}$ in Yogyakarta tinged with modernity that grows as the continued development of the plantation economy, particularly sugar cane and indigo. (Margana, 2013) Plantation economy did bring a huge economic impact to the community, even though it is not a Muslim Bumiputera community to get a direct impact on the development of plantations because most of them live in villages and mutihan fief which incidentally free of any obligations associated with plantation, such as Kotagede, Karangkajen, and so forth. Their economies are more reliant on the efforts of non-farm such as silver and batik to sustain life. 
The existence of private plantations in Yogyakarta indirect impact on urban planning changes of Yogyakarta. Starting from the expansion of the colonial area that was originally only in Lodji Gedhe, face of city grow until the advent of public facilities that become a mirror of modernity, among others, the post and telegraph offices, banks, insurance offices, shops, station, and so forth. (Budi, 2010) So also the increasing numbers of Europeans who seek plantations in Yogyakarta also give effect to the lifestyle and mindset of the people of Yogyakarta, including Muslim Bumiputera.

Muslim Bumiputera in Yogyakarta living in the shadow of the two rulers. The first ruler is the feudal government of Yogyakarta Sultanate and Kadipaten Pakualaman and second is the colonial rulers, Resident Yogyakarta. Associated relations with feudal power, the Muslim Bumiputera community bound by patron-client relationship with a ruling Sultan, since all the land in the area are owned by the Sultan of Yogyakarta Sultanate and society, including Muslim Bumiputera only be occupied with use rights. Therefore, they must be fully obedient to the Sultan as the owner of the land they occupy. The whole religious affairs are in the hands Kawedanan Pengulon of Yogyakarta Sultanate. (Darban, 2011) ${ }^{2}$ While relations with the colonial powers, Muslim bumiputera tied to the colonial policies were the highest structure in the hands of the Governor General. Muslim Bumiputera policy to specifically within the scope of work Advizeur voor Inlandsche Zaken which has a policy of cautious enough to the Muslim Bumiputera especially after Java War in 1830 until the Aceh war that finished in 1899. (Hurgronje, 1973)

Kawedanan Pengulon be the only institution authorized to handle religious affairs in Yogyakarta Sultanate. This institution oversees 20 mosques including mosques Gedhe Kauman and mosque Pathok Negoro were owned by Sultan. Mosques are located in regions fief. Most mosques owned by Sultan also features pasareyan (graveyard) were also owned by Sultan. Mosques and graveyard were conceptualized as sultan endowments (waqf) managed by Kawedanan Pengulon. Indirectly the presence of mosques owned by Sultan guarded by the courtiers of religion is also a symbol of political ties with the Bumiputera Muslim who live in the territories of the fief. Through mosques that were collected tithes at each end of the month of fasting then distributed to the courtiers. (De Indische Courant, February 25, 1931) ${ }^{3}$ That tithes was a charity in the old conception that made by the Muslim Bumiputera before 1914, the year of the turn Kiai Khalil Kamaludiningrat prince who died later replaced Muhammad Kamaludiningrat who put changes in policy.

\section{LITERATURE REVIEW}

Selosoemardjan in Perubahan Sosial di Yogyakarta describe the condition of Yogyakarta Sultanate during the reign of the Dutch Colonial that still occupied the Dutch East Indies, including Vorstenlanden. (Selosoemardjan, 2009) Major interventions in the Sultanate of Yogyakarta one of which resulted in the shifting of land tenure models. Dutch Colonial Government goal of course is only driven economic factors in order to give an opportunity to foreign plantation companies to invest and take control of land in Yogyakarta, especially for the cultivation of sugar cane and indigo. 
The implications of the economic interests of the Dutch colonial government was the birth of the Yogyakarta Sultanate policy named Land Tenure System Reorganization as described Nur Aini Setiawati (2011) in Dari Tanah Sultan menuju Tanah Rakyat. The implementation of policies that lasted from 1917-1925 was aims to "reorganize the system of ownership and control of land in Yogyakarta which was originally a property and suzerainty". This is due to the king's lands do not have a clear legal status, so that there are no regulations governing pemidahan property rights such as trade, leasing, grants and endowments as well.

Exposure of historical endowments of land and buildings in Yogyakarta, especially around development milestones endowments in Yogyakarta in the 1920s-1930s did not exist that comprehensively writing. ${ }^{4}$ But not the case with philanthropy in general, Abdurrahman Surjomihardjo (2008) in Kota Yogyakarta Tempo Doeloe which states that in 1923 the Muhammadiyah has had a Kweekschool and HIS in Notoprajan, Loro Ongko schools in Bausasran, Kauman and Karangkajen with the total number of 40 teachers and 974 students. Based on these data, this study makes it possible to trace the origins of the building further, which is very likely derived from endowments managed by instituting generosity. Likewise based on records Bambang Purwanto that PKO belongs to Muhammadiyah in Yogyakarta in the mid 1920's who has been managing a poor house, two orphanages and a health clinic can also be traced the same thing in order to trace the development milestone generosity of Islam in Yogyakarta as well as the institutionalization process carried out by Islamic organizations are growing in that period. (Purwanto, 2008)

Amelia Fauzia (2013) with dissertation Faith and the State: A History of Islamic Philanthropy in Indonesia, filling the space of historical study of endowments and philanthropy Islam in Indonesia. Despite its very long temporal and broad enough studies that include the Dutch East Indies, but specifically Fauzia also mentioned the growth of philanthropy and generosity in Yogyakarta, especially those run by Muhammadiyah. In one part of his dissertation, Fauzia Islam philanthropy comparison exposes managed in the colonial era after independence. In the period before independence, Amelia tried to map out how the colonial government's role in regulating the regulation of philanthropy and how the development of institutions that intersect with zakat and waqf that mosques and schools. A discussion of Nahdahatul Ulama and Muhammadiyah contestation in managing zakat and fitrah also eluded Fauzia. Meanwhile, after independence, the discussion covers the development of philanthropy Islam during the war of independence, and also how to modernize the management of waqf after independence. Compared with Fauzia dissertation, this thesis still has room to develop a discourse, especially on the transformation and institutionalization of charities in the period 1920s-1930s. (Fauzia, 2013)

Contrary to what is written Fauzia, Hilman Latief (2012) who wrote his dissertation with the title of Islamic Charities and Social Activism: Welfare, Da'wah and Politics in Indonesia, is more present conceptually that Islam has dimensions of welfare generosity, political propaganda and the temporal more contemporary. In terms of welfare, Latif describes the development model of generosity through free clinics, hospitals, health care programs of the three organizations namely Dompet Dhuafa, Rumah Zakat Indonesia and Muhammadiyah. Moreover, in the welfare aspects Hilman also review the charity in an effort to empower 
women with one of the issues of trafficking in women. In the propaganda, Latif tried to analyze an Islamic missionary activity in a location that Muslims are a minority, namely the island of Nias. Finally, the political side, Latif tried to explain that in many cases the charity is also built on political sentiment, for example the issue of Palestinian liberation, anti-Jewish and antiAmerican. (Latief, 2012)

When compared with the literature above, this article is still possible to fill empty space on the generosity of historical studies in Yogyakarta on the period of the 1920s-1930s. Starting from the map the socio-historical conditions of Yogyakarta at the end of the XIX and early XX century later saw the transformation of the movement to grow and generosity in Yogyakarta later endowments and philanthropy is institutionalized by Islamic organizations in Yogyakarta, including among women.

\section{RESEARCH METHODOLOGY}

This study used historical research and socio-economic approach. ${ }^{5}$ According Kuntowijoyo (2005), historical research has five stages, i.e. (1) selection of the topic, (2) collection of sources, (3) verification of historical facts and source criticism, (4) interpretation, such as analysis and synthesis, and (5) writing. Researchers determined that this research topic is the Islamic charities in late Colonial period. According Kuntowijoyo, selected topics in historical research should be based on emotional closeness and intellectual of researcher.

The themes of socio-economic study on charities in Islam is had not been much done by researchers. That is why researcher is interested in filling the void of historiographical study of Islamic studies, particularly related to the strength of civil society in the late of colonial period in relation to charities. With the provision of some previous studies that have been done related research activities and Islamic charities, researchers developed the study.

The next stage of the process of historical research is the search for the source. It was begun from sourcing process of determining the theme and then collecting both primary and secondary sources with source criticism. Primary sources obtained from the archives Hoofdbestuur Muhammadijah, Annual Official News of Muhammadiyah, Magazines Soeara Muhammadijah as well as some of the colonial press that published in the period 1920s-1930s (De Indische Courant, Soerabaijasch Handelsblad, De Sumatra Post, Het Nieuws van den Dag voor NederlandschIndie, Algemeen Handelsblad, etc.) that is accessible from kranten.delpher.nl page.

Moreover, the colonial official reports such as the Colonial Verslag, Jaarboek overzicht van Nederlandsch Indie, Dagregister and Regering Almanaak also was used to complete this study. Library newspaper collection at the Centre and the National Library also add a reference to the study.

In addition to the archives, this is done through the excavation of oral history (oral history) with interviews to better resource wakif or family who live in the period was the extent possible. Interviews were developed with the snowball method by asking informants who were interviewed other sources knew that if he could also explain about the charities in Yogyakarta in the respective period.

For secondary sources such as books, theses, dissertations and journal utilize library facilities in Jakarta and Yogyakarta. References to books mostly obtained from Integrated 
Library Center of UGM, UGM Hatta Corner, Library of the Faculty of Humanities, Department of History UGM Library, and Library St. Ignatius Kotabaru. Online journal references from various portals also were added-on library research; in addition, some of the author's personal collections are also become secondary source research. The last stage of research is interpretation and then the writing of historical narrative.

\section{FINDING AND DISCUSSION}

Transformation of Islamic charity in Yogyakarta in 1912-1931 have stimulated by the four moments. First is the impact of long-expansion European private-owned plantations in Yogyakarta. (Sri Margana, 2013) The existences of plantations in large numbers have narrowed the rural economy as well as encourage the modernization of urban Yogyakarta. (O'Malley, 1988) The situation was dilemmatic, on the one hand creating social inequality that gave rise to the urban poor, on the other hand the economic opportunities that benefit certain groups. Second is the implementation of the reorganization of land in the region of Yogyakarta Sultanate. (Nur Aini Setiawati, 2011) This policy has shifted the land tenure status of the Sultan to the public so as to enable people to distribute their assets to others. (Sesana, 2010) Third, the emergence of "urban students" as a new middle class in the cities of Yogyakarta, which has a new religious consciousness and the strength of the economy, especially nonfarm. (Kuntowijoyo, 1991) It is they who then fill such organizations Islam and creating a new social movement, including charities. Fourth is dynamic and openness Kawedanan Pengulon Yogyakarta Sultanate. Substitution Hoofdpenghulu in 1914 made Kawedanan Pengulon more open to respond to the presence of Muslim organizations in that period so that they have the opportunity to participate in the management of charities that previously only carried out by Kawedanan Pengulon. (Muarif, 2010)

Those Four moments above relate to each other and demonstrate linkages with one another. Social inequality in urban areas due to the imbalance of economic distribution then led to the urban poor. While the reorganization of land that opens the opportunity to distribute land to others to bring charitable-donations of land that was born from a strong religious awareness of the new middle class who are members of Islamic organizations and opportunities to create charitable activities by Islamic organizations for poor people. The relation between the moments supported transformation and then institutionalization of Islamic charities in Yogyakarta in the period 1912-1931.

The shift model of waqaf and charities that developed in the 1920s-1930s in Yogyakarta was marked by three significant things. First is the shifting of concept of waqf being more specific and growing variant of Islamic charity. Second is shifting of model charities with the short-term impact for those who received the charities toward the long-term impact. Third is shifting of the authority managing the generosity from Kawedanan Pengulon to socio-political organization of Islam in that period.

\section{THE DEVELOPMENT OF WAQF CONCEPT}

If the previous charities, as in Surjomiharjo's record, interpreted as an institution "desa mutihan" which was the village administration given by Sultan to society in which manages 
the mosque and tomb of the sultan and was released in the management of land without giving tribute to the sultan, the concept of waqf turned into more specific i.e. " personal gift in the name of Islamic law". (Surjomiharjo, 2008) That is, waqf no longer significantly narrower, "fief that was given by the sultan," but more than that. When people can own the land on behalf of private, it makes possible for them also to give away their waqf or property, especially land for religious purposes.

Before discussing the details of waqf of land, it is important to look at some things about patterns of control, ownership and use of land traditionally in the region of Yogyakarta Sultanate, especially comparing before 1918 and thereafter. That year was a milestone change in the pattern of control, ownership and use of land in the region of Yogyakarta Sultanate. Prior to 1918 , the pattern of control, ownership and use of land in the region of Yogyakarta Sultanate was still feudal. (Murniatmo, et al., 1989) All existing land is the property of the Sultan. To ensure the supervision and management of the land of the Sultan who is far from Kraton (Kutagara) by the Sultan handed over to the nobles (the royal family) or the palace officials (pangrehpraja). They are then called obedient (abdi dalem). Rights attached to them are right anggaduh, the authority to manage land that has become their privilege. In the lands controlled by patuh, stay the palace servant (kawula dalem) who has the right anggarap but had to give up some results from their privilege an obligation to patuh. To relieve his duties, patuh lifted bekel to be their subordinate. Bekel that lifted the village comes from the structural element which has the power to perform control functions with feudalism bandage. (Suhartono, 1991)

In the region of Yogyakarta Sultanate, the ending of kebekelan and kepatuhan was marked officially by the implementation of Rijksblad Sultanate No. 16, 1918. The new regulations eliminate the feudal role of patuh and bekel and hand it over to the village as penggaduh named right andarbe. (Murniatmo, et al., 1989) Based on this new regulation also, the land users (kawula dalem) has a new status that as a user of land with the right anganggo that hereditary (erfelijk gebruiksrecht). Issuance of Rijksblad Sultanate No. 25 in 1926 and Rijksblad Pakualaman No. 231926 reinforce the rights owned by the village, andharbeni rights, namely to rule the lands in the area of the village, except those that have cultivated by villagers. Means, except the land that cultivated villagers, all of land are communal lands/ common property. It was owned by village as the village treasury. (Rijksblad Kasultanan No. 25 of 1926 and Rijksblad Pakualaman No. 23 of 1926) Andarbe land and apanage are entitled village's officials then also be taxed by the Sultanate. (Murniatmo, et al., 1989)

Before Verklaring Rijksblad domain of Sultanate No. 161918 junto No. 23, 1925 was set, all the land is owned by the Sultan. (Rijksblad Kasultanan No. 16 in 1918 and Rijksblad Sultanate No. 23 in 1925) the Sultan's land property rights are regulated as follows: 1) land that is used solely by the sultan's palace (Keprabon land) and land to the tomb of Sultan and Sentono palace, 2) The land given to the use rights to the Dutch government for the office, school, home mortgage, boarding military/police and railways, 3) the land given to the NIS for the railroad (regulated by the concession), 4) land for foreigners with the right engindom/opstal, 5) land for plantations (ondernaming) also factories and housing (arranged by concession), 6) ground for relatives / Sentono king (kesentanaan ground), 7) land given for the post of courtiers Sultan like Pepatih Dalem, Bupati Nayoko, Bupati, Wedono Panewu and Villages (In 1921 
based Rijksblad Sultanate No. 1 in 1921 the land in lieu of salary is repealed and replaced salaries paid, except for the village), 8) of land for fruit crops (kebonan land), 9) of land for the development of Islam (mutihan land). ${ }^{6} 10$ ) ground gave for meritorious officials (perdikan land), 11) yard land to the people present in the city with the right anganggo, and 12) of land to people outside of the city with the right anggarap. (Murniatmo, et al., 1989)

After declaring Rijksblad all apanage is wholly owned by Sultan and became property of the Sultanate. Rights of the people who at first can only use (anggarap right) became owning rights (andarbe rights) hereditary that can be pawned or sold. People have the angganggo right is called kuli kenceng. However, the rights granted are not free because the rights holder is required to pay taxes stipulated in the Sultanate Rijksblad No. 11, 1920 about land tax. (Murniatmo, et al., 1989) This is where the beginning of the privatization of land for the community. Anganggo rights which owned by the people is then also lowered the other rights that pledge, sale, exchange, donation and including waqf. So, waqf is no longer significantly narrow strip of land at the same mutihan land that given by Sultan to the Muslims and abdi dalem for religion affairs.

\section{SHIFTING OF CHARITIES GOALS FROM SHORT TERM TO LONG TERM}

Until the beginning of the 20th century, not many people who could channel their charities due to limited economic domination and feudal bond agencies/institutions that accommodate the public charities. Then the concomitant changes in the dynamics of Yogyakarta in the early twentieth century, people with surplus-owned economy and the existence of Islamic socialpolitic organizations that build loyalty and modernization bond that developed in Yogyakarta when it is, then the charities with various variants emerge. Generosity grows from simple to more complex and longer usefulness.

Some models of charities movement flourished in Yogyakarta in the 1920s-1930s. Besides zakat fitrah that paid once a year at the end of Ramadan (De Indische Courant, February, $25,1931)$, on the first movement of growing charities is more internal in order to gather support compulsory and voluntary support for Islamic charitable organizations. Support was mostly used for the operational needs of the organization. In development, there is the collection of donations earmarked for social purposes such as the construction violated, disaster donations, donations for orphans and the poor, the collection of zakat until then appeared waqf. ${ }^{7}$

Islamic organizations are growing in Yogyakarta in the early twentieth century such as Muhammadiyah, Sarekat Islam and other small scale Islamic social organizations to develop the types of such charities to ensure running of organization's activities. For example Muhammadiyah in 1921 to develop a model of charities by collecting support for periodical publishing Soewara Moehammadijah, their periodical publication, and also contribute to the establishment and operation violated PKO health clinic. (Swara Moehammadijah, October 1923) While the Sarekat Isalm through Central Sarekat Islam in addition to gathering support for publishing Bendera Islam (Islamic States had two other publications printed outside Yogyakarta: Oetosan Hindia in Solo and Fajar Asia in Batavia), the construction violated and also collecting ramp (assistance) for disaster victims. (Algemeen Handelsblad, July, 14, 1919) 
Sarekat Islam (PSI) Party through dr. Soekiman, doctors colonial government who had assigned to help operational Muhammadiyah clinic owned by PKO section, worked with PKO section for contacting home for health clinics wider in 1926. When the PSI and Muhammadiyah collected on $\mathrm{f} 2500$ and bought 24-bed clinic to clinic and PKO, though later due to incompatibility between the two, especially after Sarekat Islam to impose party discipline to Muhammadiyah, PKO health clinic when it was led by dr. Sampoerno choose to split its management with PSI and occupy another place to continue the health care work. (Soerabaijasch Handelsblad, October 8, 1931)

In addition to donate for publishing magazines, charities models that developed in the organization Muhammadiyah is collecting donation for the operation of Muhammadiyah polyclinics section of PKO. Swara Moehammadijah that published in October 1923 appears that PKO Polyclinic income derived from charitable Comite Voetbal Djokja of f203.1. In addition, it is also derived from cash from Hoofdbestuur Muhammadiyah and also the payment of sick people who can afford. Importation of crates charity ranged from f5-f15. While the average Hoofdbestuur f50. While from agencies outside Muhammadiyah is much bigger than that.

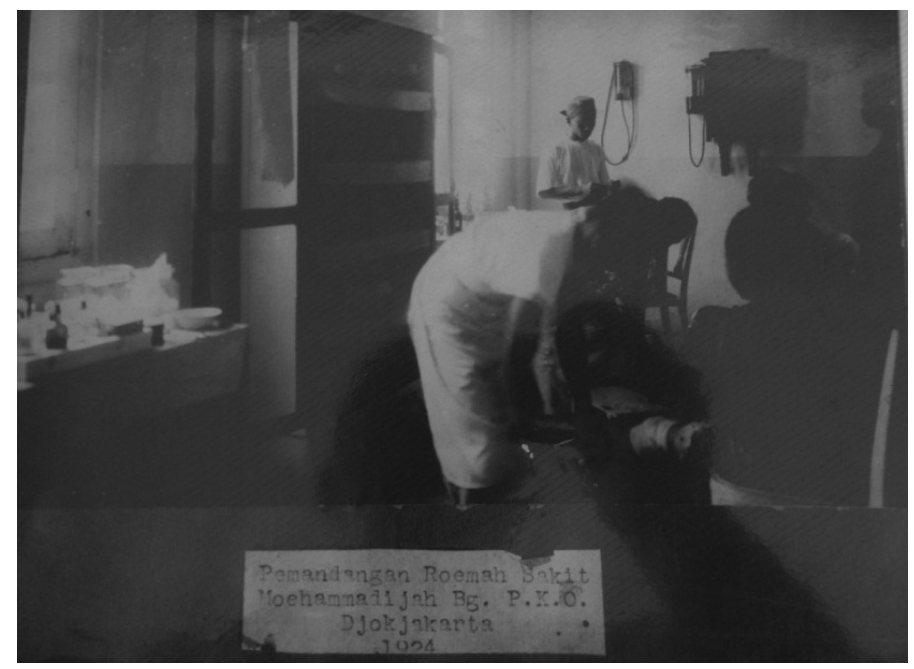

Muhammadiyah's Health Clinic in Notoprajan-Yogyakarta, 1924

Source: KH. Ahmad Dahlan Foundation

Charities which collected by PKO section were used for the operations of PKO Polyclinic among others to buy drugs, milk, bike, rent auto (car) for transporting patients, buying mattresses and pillows, eating tools and cabinets tools, pay helpers and staff, to buy bedpan, to pee patients and other small expenses. Largest expenditure is for the purchase of drugs. In the report, during the months of March to August 1923, PKO spend money collecting charity in the amount of f 261.14 just for the drug. The report noted by H.M. Soedja' as voorzitter, J. Djojowongso as secretary, and Ashari as PKO's Penningmeester. (Swara Moehammadijah, Oktober 1923)

Besides PKO, other parts of Hoofdbestuur Muhammadiyah who receive charity is Tabligh section. In the same issue of the Swara Moehammadijah of October 1923 was known that Tabligh section get $\mathrm{f} 222.06$ obtained from the donors. The average of the benefactors of the title Haj and not only from Yogyakarta, but also other cities, such as Magelang, Madiun, 
Semarang, Jember, Jombang, Lumajang. Obtaining zakat from outside the city as Tabligh section Hoofdbestuur Muhammadiyah carries out religious services in those cities. Derma that got by Tabligh section, was mostly used for travel money, but it is also used for stationery, lighting (lamp aniem), car rental and shopping retainer of staff. The financial report of Tabligh section that published on Swara Moehammadijah was reported by H. Fachrudin as President and HM Anies as Penningmeester. (Swara Moehammadijah, October 1923)

Another charity collecting utilization model was used for the construction of langgar. Swara Moehammadijah of October 1923 reported that several members of the Muhammadiyah in Kudus collected donation for the construction of women's langgar in Kauman, Yogyakarta. They gather collectively and sent to Hoofdbestuur Muhammadijah in Yogyakarta. H. Ibrahim as pemoeka and H. Fachrodin as treasurer to say thank you and report the charity collection in issued by Swara Moehammadijah of October 1923. The total amount collected is $\mathrm{f} 213$ and most of them are Hajj.

\section{FROM INSIDE TO OUTSIDE OF THE SULTANATE PALACE BETENG}

Beside charity, tithe as a religious order must be accomplished at the end of Ramadan, has been administered annually by Kawedanan Pengulon. Kiai Penghulu through bureaucratic structures in Kepengulonan, coordinated the collection of tithe through Kagungan Dalem mosques scattered in many perdikan villages/mutihan in Yogyakarta. As an institution at Keraton authorities in religious matters, in addition to maintaining Great Mosque of Yogyakarta Sultanate and broadcasting Islam by organizing the five daily prayers, Kawedanan Pengulon does get the authority of the Sultan for the management of zakat, infaq/sadaqah, and waqf from public or Sultan itself. (Isma'il, 2007) Kawedanan Pengulon led by a Kiai Pengulu also called Penghulu Ageng/Hoofd Penghulu. (Darban, 2011 and interview with Ahmad Muhsin Kamaludiningrat)

The presence of a Muslim social organization Muhammadiyah in Yogyakarta also began takes a role in the collection and distribution of tithe. Soeara Moehammadijah published in 1923 reported that thousands of tithe payers submitted their tithe to Muhammadiyah to be redistributed to people in need. (Soeara Moehammadijah, December 1923) There has not been enough resources whether Sarekat Islam also do the same thing with Muhammadiyah in management of tithe.

If previously Kawedanan Pengulon managed waqf belonging to the sultan in the perdikan villages/mutihan, Hoofdbestuur Muhammadiyah also then manage land waqf from Yogyakarta people along with the shifting land rights from the sultan to the public in 1920. Starting from tithe, the Islamic charity gained momentum when the ownership of the land personally given by the Sultanate Palace over the reorganization of land so as to enable the public to give their waqf over the land. Islamic social organizations have been managing charity and other charities then also get waqf, both land and buildings of the public or members of the growing loyalty.

Some land waqf obtained by Muhammadiyah in 1920, among others, a plot of land to build Kweekschool for women in Notoprajan which is the waqf of Haji Fachrodin, brother of Haji Syoedjak and student of KH Ahmad Dahlan and also a batik trader. There was also a piece of land in the town which was then built on it the clinic and the clinic is PKO section which is waqf from Haji Bakar (Mas Atmosudigdo's son, a big trader in Kotagede) and some other 
members of Muhammadiyah at the end of the 1920s. In Karangkajen, Muhammadiyah also receive land waqf that used to build orphanage from Jundan Abdullah Hadi and Harun' family. In addition there is also soliciting donation collectively to establish Ongko Loro schools and Hollandsch-Indlandsche Cursus of Muhammadiyah from silversmiths in Kotagede afforded by Amir and Kiai Kiai Masyhudi. (Nakamura, 1980)

Besides take in waqf land and building, Muhammadiyah also obtained gebruik rights of Sultan and Pakualam to build Desaschool in Pakualaman, Bintaran Lor, Ngupasan, Notoprajan, Suronatan and Loro Ongko School in Bausasran, Kauman, Karangkajen. Although just get land use rights but Muhammadiyah can use it with unlimited time as long as it is still used for the benefit of public services. Muhammadiyah tried to accumulate that waqf for internal purposes and also for public services.

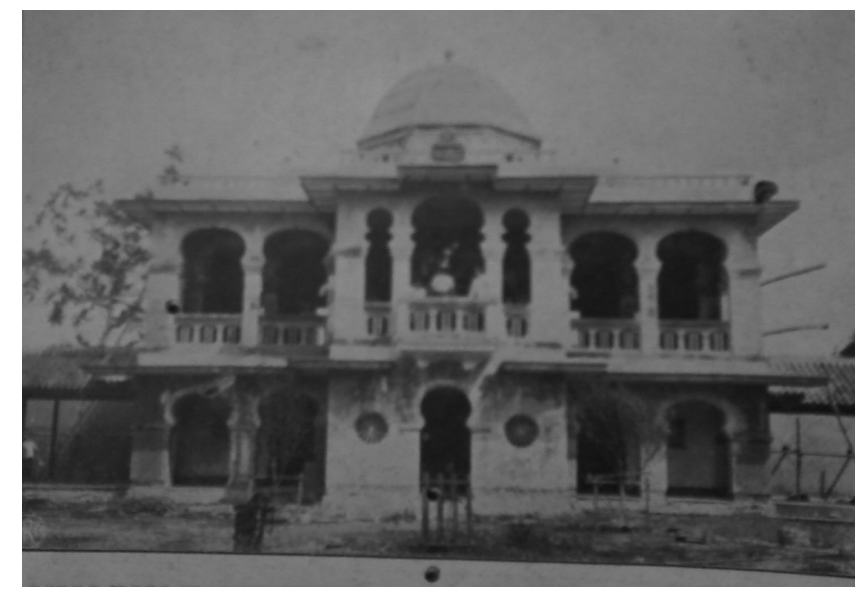

Mosque Complex of Muhammadiyah's Orphanage, Toengkak-Yogyakarta, 1930an

Source: Masdjid dan Makam Doenia Islam, tt, hlm. 28

The shift manager of tithes from Kawedanan Pengulon to Muhammadiyah also marked a change management culture. Previous feudal tithe managed utilizing Kawedanan Pengulon legitimacy as a religious institution that is very binding Bumiputera Muslim community in the area of Yogyakarta Sultanate. With 20 mosques, Kawedanan Pengulon exploit the charities collection especially pitrah only to meet the needs of the courtiers who are considered as wages courtiers pamethakan and not re-distributed to the poor as to which destination pitrah itself. (Nakamura, 1983) When began to take on the role of managing tithes in 1914, Muhammadiyah collecting and then redistributed to the poor in Yogyakarta without taking part of the pitrah.

Since getting the trust from Hoofdpenghulu in 1914 to manage tithe, Muhammadiyah tried to continue the work of their ministry in terms of wider. Then, forms of Muhammadiyah service work more dynamic, especially after the eruption of Mount Kelud in 1919 that lead to more than 5000 people died, although Muhammadiyah itself is no more dynamic role of Islamic States in Kelud aid disaster victims. In 1920 the momentum when Hoofdbestuur Muhammadiyah formed four sections in the management structure, which is part of Teaching, Part Tabligh, Part Library, and Section PKO. Under Soedjak leading, Section PKO becomes prominent enough to establish the magnitude of the ideals of the hospital, poorhouse (armenhuis) and orphanages (weeshuis). (De Indische Courant, June 16, 1926) 
The realization of section PKO's great ideals was in 1923 with the establishment of health polyclinics and managed poor house in Ngabean street. Eight years later, PKO also realize the establishment orphanages in Toengkak Lowano. With its service agencies, Section PKO can be quite dynamic in generosity institutionalize the good of the Colonial Government, Sultan Ha mengku Buwana, Adipati Pakualam in the form of subsidies and also the main committee and members of Muhammadiyah itself in the form of charity and waqf. Subsidies, charities and other charities are managed to continue to be used to implement services to residents of Yogyakarta in need. This is the form of institutionalization generosity made Hoofdbestuur Muhammadiyah through the establishment of PKO section. In addition, Section Teaching Hoofdbestuur Muhammadiyah and her organization, 'Aisyiyah, also get subsidies and collecting charity to run education services through the school and kindergarten. (Mu'arif and Hajar Nur Setyowati, 2014)

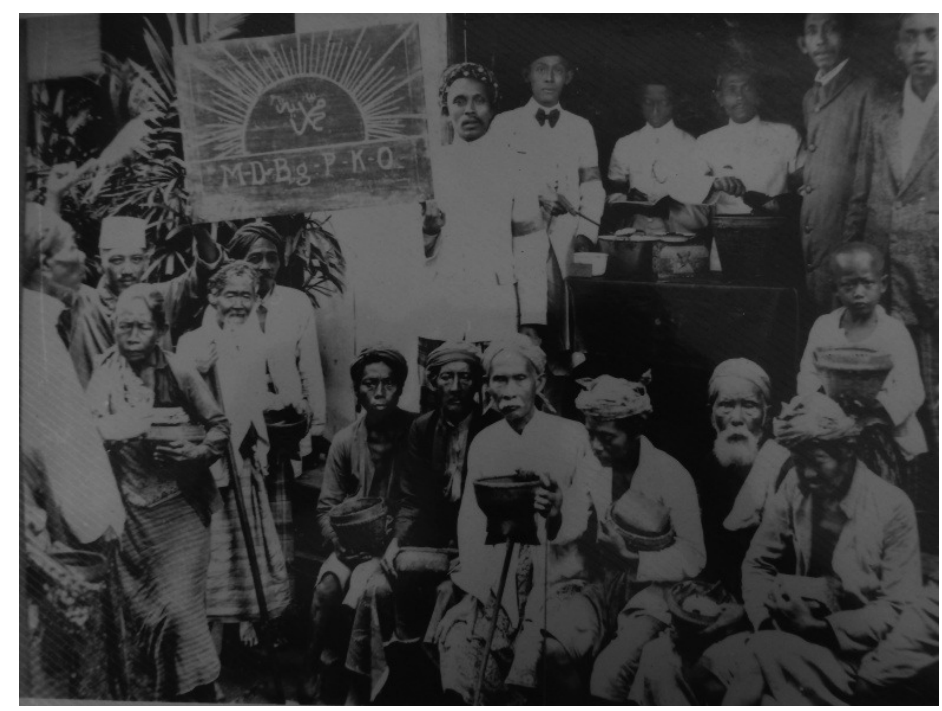

Zakat Distribution Activity by Hoofdbestuur Muhammadiyah of PKO Section to the Poor Source: KH. Ahmad Dahlan Foundation

In general, when compared to the Serikat Islam, Muhammadiyah's charities institutionalization was more dynamic for two reasons. First, the choice of making a political move in the region of Islamic States become less focused in carrying out the work of ministry, especially after the outbreak in 1921, despite the disaster victim services program as was the case when the eruption of Mount Kelud in 1919 instead of Sarekat Islam which stands foremost. While Muhammadiyah who chose engaged in the social and education even more stable and widely trusted by the population of Yogyakarta to entrust their charities. Second, the choice of Muhammadiyah for well cooperative policy with the Dutch colonial government in Yogyakarta also Yogyakarta Sultanate and the Adipati Pakualaman very helpful Muhammadiyah accessing subsidies to develop their service work.

Sarekat Islam, Muhammadiyah, 'Aisyiyah and other Islamic organizations mobilize the charities from internal organization for the benefit of the organization's internal and external also in many models of medical services through the clinic, welfare benefits through poorhouse and orphanage, the establishment of schools begin kindergarten, HIS until Kweekschool, broken 
for the construction of women's centers, publishing periodicals as well as activities of Tabligh (lighting) religion. The activity is a representation of the strength of civil society who are able to do roles beyond those performed traditional colonial state and government in Yogyakarta.

The presence of new institutions that make the process of institutionalization was part of the process of shifting authority managing of waqf. At the same time, the openness of the institution of Kawedanan Pengulon to the presence of Muslim organizations in Yogyakarta other things smoothen the institutionalization of charities in Yogyakarta. That said, the management authorities Islamic charities began to migrate to the outside of Sultanate Palace's Beteng. Feudal bond was replaced with a rational bond. The social function of religion that were previously wrapped feudalism religious bureaucracy in Yogyakarta palace was changed.

\section{CONCLUSION AND RECOMMENDATION}

The moments of strengthening plantation that impact increasing of poor man in urban Yogyakarta, land redistribution in Yogyakarta Sultanate beginning 1911, emergence of new Isalamic social-politic organization, shifting of Kiai Penghulu in Kawedanan Pengulon 1914, brought social-economic implication in Yogyakarta region. Islamic social-politic movement, such as Muhammadiyah and Sarekat Islam, could take over the role to collect and to redistribute tithe, accepted land waqf and created new concept of charities. Loyalty that got from their member supports the big shifting in history of charities in Colonial period.

When seen from the perspective of sociology of religion, charities activities by Islamic social-politic organizations in the period 1920s-1930s in Yogyakarta shows the back of social function of religion after a long pulsed actualization banded by feudalism of Kawedanan Pengulon Yogyakarta Sultanate structure. In addition, charities activities could also be seen as a response to colonialism in ways that are elegant. The absence of colonial state on caring Bumiputera community welfare, invited the movement performed by Islamic social movement as civil society in managing new charities.

Charities activities managed by Islamic social movements in the second of decade twentieth century was unlike the models of resistance at the end of the nineteenth century that tend confrontational in the form of rebellion. By this new model of social movements, Islamic social organization in Yogyakarta at that time showed the urbanized character of community in the late of Colonial period.

If this phenomenon is seen only as a form of modernizing Islamic movement, it would be too narrow explanation. But look at this phenomenon from the perspective of socio-economic history will bring a wider understanding that there is a social and economic situation, which led to the idea of reform undertaken presence of social movements and political Islam in the early twentieth century through the activities of charities. 


\section{REFERENCES}

Algemeen Handelsblad, July, 14, 1919

De Indische Courant, June 3, 1924

De Indische Courant, June 16, 1926

De Indische Courant, February 25, 1931

Rijksblad Kasultanan 1920 No. 11

Soeara Moehammadijah, October 1923

Soeara Moehammadijah, December 1923

Soerabaijasch Handelsblad, June 261929

Soerabaijasch Handelsblad, January 8, 1930

Soerabaijasch Handelsblad, October 8, 1931

Amelia F. (2013). Faith and the State: a History of Islamic Philantrophy in Indonesia. Dissertation. Belanda: Brill's Southeast Asian Library.

Bambang, P. (2008). Capitalizing Charity in Indonesian Muslim Community: The History of PKU Muhammadiyah-Aisyiah Hospital. International conference on "Indigenous Charities: Historical Studies of Institutions Across Culture”, Hongkong 6-7 November 2008.

. (2010). Dimensi Ekonomi Lokal dalam Sejarah Indonesia, dalam Sejarah Indonesia Perspektif Lokal dan Global: Persembahan untuk 70 Tahun Prof. Dr. Djoko Suryo. Yogyakarta: Ombak.

Farid, W. dan Mursyid. (2007). Wakaf dan Kesejahteraan Ummat Filantropi Islam yang Hampir Terlupakan. Yogyakarta: Pustaka Pelajar.

Geertz, C. (2013). Agama Jawa. Jakarta: Komunitas Bambu.

Hilman, L. (2012). Islamic Charities and Social Activism: Welfare, Dakwah and Politics in Indonesia. Dissertation. Netherland: Leiden Universiteit.

Hurgronje, S. (1973). Islam di Hindia Belanda, translated by Koentjaraningrat, et. al., Jakarta: Bhatara.

Kuntowijoyo. (1991). Paradigma Islam: Intepretasi untuk Aksi. Bandung: Mizan. . (2003). Metodologi Sejarah. Yogyakarta: Tiara Wacana. . (2005). Pengantar Ilmu Sejarah. Yogyakarta: Bentang,

Muarif. (2010. KH. Mohammad Kamaludiningrat: Sang Penghulu Reformis. Basis, (07-08), Tahun ke-59.

Mu'arif dan Setyowati, H. N. (2014). Srikandi-srikandi 'Aisyiyah. Yogyakarta: Suara Muhammadiyah. 
Nakamura, M. (1983). Bulan Sabit Muncul dari Balik Pohon Beringin. Yogyakarta: Gadjah Mada University Press.

Nur A. S. (2011). Tanah Sultan Menuju Tanah Rakyat. Yogyakarta: STPN Press.

O’Malley, W. J. (1988). Sejarah Ekonomi Indonesia. Jakarta: LP3ES.

'Sejarah", Available via www.muhammadiyah.org., [accessed January 10, 2015].

Sri, M. (2013). Pesanggrahan Ambarrukmo. Yogyakarta: Royal Ambarrukmo Hotel and Kompas Gramedia.

.et. al. (ed.). (2010). Kota-kota di Jawa: Identitas, Gaya Hidup dan Permasalahan Sosial. Yogyakarta: Ombak.

Suhartono. (1991). Apanage dan Bekel: Perubahan Sosial di Pedesaan Surakarta 1830-1920. Yogyakarta: Tiara Wacana.

Interviewee:

Ahmad Muhsin Kamaludiningrat (67) at Kauman, January 28, 2015.

(Endnotes)

1 "Muslim Bumiputera" intended in this discussion is the native santri in terms Kuntowijoyo that identified with Islamic cultural orientation and not adat/tradition or secular. See: Kuntowijoyo, "Muslim Kelas Menengah Indonesia 1910-1945: Sebuah Pencarian Identitas", dalam Paradigma Islam: Intepretasi untuk Aksi, (Bandung: Mizan, 1991), p. 80.

2 Pengulon oversees Surambi court or also known as the al-Mahkamah al-Kabiirah that being competent authority in deciding the cases of religion. It also collects tithes and manages the mosque and tomb of the Sultan were scattered in the Yogyakarta Sultanate. See: Ahmad Adaby Darban, (2011) Kauman: Menguak Identitas Kampung Muhammadiyah, (Yogyakarta: Suara Muhammadiyah, 2011), p. 11.

3 De Indische Courant, February 25, 1931 reported that the activities of the Muslim community in Vorstenlanden at the end of the fasting month is "offeren hun pitrah aan den modin" (expense/pay their nature to modin) and "schatting aan het armenfinds" (giving zakat to the management body of compensation for the poor).

4 Farid Wadjdy and Mursyid once wrote in Chapter III of their book. They wrote regulation of waqf at the time of the Dutch East Indies. In addition to Bijblad 6196 and 1931 of the 1905, Bijblad No. 1253, 1934 Bijblad No. 13 390 , and Bijblad 1935 No. 13480, other sources to declare endowments already existed since the sixteenth century seems to me doubtful. See: Farid Wadjdy dan Mursyid, Wakaf dan Kesejahteraan Ummat Filantropi Islam yang Hampir Terlupakan, (Yogyakarta: Pustaka Pelajar, 2007), p. 38-43.

5 This study categorized social history due to examine the social aspects of the socio-religious life of the people in Yogyakarta period of 1920s-1930s. See: Kuntowijoyo, Metodologi Sejarah, (Yogyakarta: Tiara Wacana, 2003), p. 39 dan Bambang Purwanto. "Dimensi Ekonomi Lokal dalam Sejarah Indonesia", dalam Sejarah Indonesia Perspektif Lokal dan Global: Persembahan untuk 70 Tahun Prof. Dr. Djoko Suryo, (Yogyakarta: Ombak, 2010), p. 495.

6 I do not think mutihan land categorized into land grants or donated land because mosques and tombs that stood on the land still serve Kagungan Dalem (the Sultan) and its management under Kawedanan Pengulon. That is why 
mutihan land more appropriately called the land of the Sultan, although labeled as ground mutihan meaningful land given by the sultan for religious activities. White is synonymous with religious identity that is the opposite of red or abangan. Related identity of putihan/mutihan and abangan, see: Clifford Geertz. Agama Jawa. (Jakarta: Komunitas Bambu, 2013), p xxx-xxxi.

7 Related collecting donation for the disaster, Sarekat Islam was to be more proactive than Hoofdbestuur Muhammadiyah. An article of Algemeen Handelsblad, July 14, 1919 reported that the Central Sarekat Islam led by HOS Tjokroaminoto raise up to $\mathrm{f}, 800$ as assistance for victims of the eruption of Mount Kelud in Blitar. 